\title{
CLINICAL COURSE OF CHRONIC HEART FAILURE WITH PRESERVED EJECTION FRACTION AFTER RADIOFREQUENCY CATHETER ABLATION FOR ATRIAL FIBRILLATION
}

\author{
Zolotarova T. V., Brynza M.S.
}

Introducrion. Recent randomized controlled trials suggest that catheter ablation of atrial fibrillation (AF) in heart failure (HF) patients leads to improvements in left ventricular function, exercise capacity, and quality of life, but focused on HF with reduced left ventricle ejection fraction (LVEF).

Aim. To study the clinical course of chronic heart failure with preserved ejection fraction after radiofrequency catheter ablation for atrial fibrillation.

Materials and methods. 194 patients with $\mathrm{AF}$ and chronic $\mathrm{HF}$ with preserved ejection fraction were included in the study: 136 patients - underwent catheter ablation (CA) for AF; 58 - control group, who continued pharmacological therapy (PT) for rhythm control strategy. All the patients had New York Heart Association (NYHA) class I, II or III HF, LVEF > $40 \%$. Baseline characteristics comprised demographic and clinical data, medical history echocardiography and ECG results of the included patients.

Results. Patients on PT were significantly more symptomatic for HF in comparison to CA patients (the average value of NYHA class HF 2,2 \pm 07 versus (vs.) $1,8 \pm 0,6 ; p=0,019$ ), but AF for itself were more symptomatic in CA group (the average value of EHRA 3,1 $\pm 0,5$ vs. $2,9 \pm 0,6 ; p=0,001$ ). Among patients with HF with preserved LVEF who underwent CA and were followed-up 24 months $52,9 \%$ of patients remained free of AF recurrence; while in the control group only $7 \%$. At the 24 months follow-up NYHA class significantly improved in ablation group, as well as EHRA score.

Conclusions. Radiofrequency catheter ablation was associated with improved the clinical course of chronic heart failure with preserved left ventricle ejection fraction and $\mathrm{AF}$ - related symptoms itself.

KEY WORDS: heart failure, catheter ablation, atrial fibrillation, clinical course

\section{INFORMATION ABOUT AUTHORS}

Tetiana Zolotarova, Assistant of Department of Propaedeutics of Internal Medicine and Physical Rehabilitation V. N. Karazin Kharkiv National University, School of Medicine, 29, Akademika Kurchatova Av., k. 1, 3 floor, 1 room, Kharkiv, Ukraine, 61108. e-mail: tatiana.zolotarova@karazin.ua, ORCID ID: https://orcid.org/0000-0001-6226-6769

Mariia S. Brynza, candidate of Medicine, Head of the Department of Propaedeutics of Internal Medicine and Physical Rehabilitation V. N. Karazin Kharkiv National University, School of Medicine, 29, Akademika Kurchatova Av., k. 1, 3 floor, 1 room, Kharkiv, Ukraine, 61108. e-mail: m.brynza@karazin.ua, ORCID ID: https://orcid.org/0000-0002-82603600

\section{INTRODUCTION}

Atrial fibrillation (AF) and heart failure (HF) are cardiovascular disease epidemics that have grown worldwide in the past 2 decades. $\mathrm{HF}$ with preserved left ventricle ejection fraction (HF pLVEF) accounts for $\approx 40 \%$ to $50 \%$ of incident HF overall and two-thirds of the patients may at some point have arrhythmia during the course of the disease. AF seems to implicate a worse prognosis in patients with HFpEF than HF with reduced EF.

Rhythm control has been shown to achieve greater success in improving LV dysfunction with a resultant favorable impact on quality of life and survival. The greatest benefit was observed in that maintaining sinus rhythm (SR) at 1-year [1].
Radiofrequency catheter ablation (RFCA) is an effective rhythm control strategy for patients with $\mathrm{AF}$, and it has become a standard procedure for anti-arrhythmic drug resistant $\mathrm{AF}$ in current guidelines for $\mathrm{AF}$ management [2].

It is superior to antiarrhythmic drug therapy as a second-line option for maintaining SR, improving LV function and physical activity in symptomatic AF patients with or without HF [1].

Recent randomized controlled trials suggest that catheter ablation of AF in HF patients leads to improvements in left ventricular function, exercise capacity, and quality of life.

The study results from the Catheter Ablation versus Standard Conventional Therapy in Patients with Left Ventricular Dysfunction and Atrial Fibrillation (CASTLE-AF) trial has 
shown that a reduction in the amount of time in atrial fibrillation may be sufficient for clinical benefit: catheter ablation merely decreased the time in AF. While catheter ablation does not eliminate the AF per se, it can limit the ventricular rate by eliminating triggers and altering electrophysiological connections in the heart in a similar fashion to rate control antiarrhythmic drugs. Longer-duration normal sinus rhythm may improve outcomes by means of a number of mechanisms, including greater atrial emptying, all of which translate into improved cardiac output [3].

However, there are limited amount of data about clinical course, hospitalizations and complications HFpLVEF after RFCA for AF.

\section{AIM}

To study the clinical course of chronic heart failure with preserved ejection fraction after radiofrequency catheter ablation for atrial fibrillation.

\section{MATERIALS AND METHODS}

The study population consisted of 136 patients with chronic $\mathrm{HF}(\mathrm{CHF})$ with preserved $(>40 \%)$ left ventricle $\mathrm{EF}$ who underwent RFCA for atrial fibrillation that was refractory to pharmacological therapy (PT) and 58 patients from the control group who continued PT for rhythm control strategy. A diagnosis symptomatic CHF and its' functional class (FC) were made by New York Heart Association (NYHA) and current guidelines [4], a class between I and III.

Baseline characteristics comprised demographic and clinical data, medical history (coronary heart disease, hypertension, diabetes, and previous stroke or transient ischemic attack), echocardiography results and medications of the included patients (beta-blox. Coronary heart disease was defined as: symptoms such as angina, myocardial infarction, coronary angioplasty, or coronary artery bypass graft surgery. We calculated CHA2DS2-Vasc and HAS-BLED scores of each patient according to recent guidelines [5].

Heart rate $(\mathrm{HR})$ and blood pressure $(\mathrm{BP})$ were measured at rest.

A standard 12-lead electrocardiogram (ECG) was registered in all patients. QT interval measurement was done in lead II or V5 where it was best seen. The QTc interval was calculated by using Bazett's formula in patients with SR where heart rate (HR) was between 60 to 100 beats per minute $\left(\mathrm{QTc}=\mathrm{QT} /\left(\mathrm{RR}^{\wedge} 0,5\right)\right)$. If a patient had AF or HR differed from 60 to 100 beats per minute, the QTc was calculated by Framingham formula where QT interval measured from 3 consecutive cardiac cycles and then a mean value was used for analysis.

All patients underwent transthoracic echocardiography (TTE). The standard echocardiographic parameters were obtained by utilizing the techniques recommended by current guidelines [6], especially: LV EF, left and right atrium diameter (LA and RA, respectively).

After the RFCA, all patients received antiarrhythmic drugs if there were no contraindications. The drugs were discontinued if no recurrent atrial tachyarrhythmia was detected after 3 months after procedure. All patients had anticoagulant treatment for at least 3 months after the RFCA and PT for concomitant chronic HF.

The aim of the ablation procedure was to achieve isolation of all pulmonary veins and to restore sinus rhythm. Additional ablation lesions were made at the discretion of the operators.

Outpatient follow-up and electrocardiograms were performed at 6, 12, 24 months intervals thereafter. ECHO measurements were performed the day before RFCA or Day 0 is the time of the baseline visit for the patients from control group and 24 month follow-up. Recurrence of AF was defined as any episode of atrial arrhythmia that lasted longer than 30 seconds, in accordance of recent guidelines [5].

The obtained data after the formation of the database was processed in Microsoft Excel, SPSS 23.0. Distributions of quantitative variables are described as means \pm standard deviation (sd) or by median and interquartile range and compared using the Mann-Whitney $\mathrm{U}$ test. The results were indicated statistical significance for $\mathrm{p}<0,05$.

\section{RESULTS AND DISCUSSION}

In total, 194 patients with $\mathrm{AF}$ and $\mathrm{CHF}$ with pLVEF were included in this study. Of those, 136 patients were done AF RFCA and the rest 58 ones from control group received pharmacological rhythm control therapy (PRCT). Baseline characteristics are shown in table 1. 
Baseline characteristics of the study population

\begin{tabular}{|c|c|c|c|}
\hline Characteristics & $\begin{array}{c}\text { Ablation group } \\
\text { Total } \\
\text { n }=136 \\
\text { sd, } \% \\
\end{array}$ & $\begin{array}{c}\text { Control group } \\
\text { Total } \\
\mathbf{n}=\mathbf{5 8} \\
\text { sd, } \% \\
\end{array}$ & P value \\
\hline Age (years) & $59,4 \pm 9,1$ & $56,4 \pm 8,9$ & 0,068 \\
\hline Male sex, $\%$ & 46,3 & 46,6 & 0,988 \\
\hline Body mass index $(\mathrm{kg} / \mathrm{m} 2)$ & $28,2 \pm 5,1$ & $29,3 \pm 5,4$ & 0,510 \\
\hline AF duration (months) & $53,2 \pm 45,8$ & $51,4 \pm 46,6$ & 0,364 \\
\hline Frequency of paroxysms per month & $10,7 \pm 10,2$ & $4,6 \pm 4,9$ & 0,001 \\
\hline Paroxysmal & $58(42,6)$ & $15(25,9)$ & \multirow[t]{4}{*}{0,001} \\
\hline Persistent & $71(52,2)$ & $16(27,5)$ & \\
\hline Long standing persistent & $2(1,5)$ & $27(46,6)$ & \\
\hline Permanent & $1(0,7)$ & - & \\
\hline Mean NYHA class HF & $1,83 \pm 0,6$ & $2,1 \pm 07$ & 0,72 \\
\hline Mean EHRA score before ablation & $3,1 \pm 0,5$ & $2,9 \pm 0,6$ & 0,001 \\
\hline Mean CHA2DS2VASc & $2,5 \pm 1,3$ & $2,7 \pm 1,6$ & 0,625 \\
\hline Mean HAS-BLED & $1,7 \pm 0,9$ & $2,1 \pm 0,8$ & 0,126 \\
\hline Coronary artery disease & $48(35,2)$ & $10(17,2)$ & 0,016 \\
\hline Hypertension & $98(72,1)$ & $43(74,1)$ & 0,825 \\
\hline Diabetes mellitus & $18(13,2)$ & $8(13,8)$ & 0,917 \\
\hline $\begin{array}{l}\text { Stroke/Transient ischemic attack } \\
\text { before ablation }\end{array}$ & $13(9,6)$ & $5(8,6)$ & 0,802 \\
\hline $\begin{array}{l}\text { Systolic blood pressure (SBP), } \\
\mathrm{mmHg}\end{array}$ & $131,6 \pm 13,5$ & $132,5 \pm 21,4$ & 0,948 \\
\hline $\begin{array}{l}\text { Diastolic blood pressure (DBP), } \\
\mathrm{mmHg}\end{array}$ & $82,2 \pm 7,9$ & $85,3 \pm 12,7$ & 0,127 \\
\hline HR, bpm & $80,4 \pm 24,5$ & $84,5 \pm 20,6$ & 0,068 \\
\hline $\mathrm{PR}(\mathrm{Q}), \mathrm{ms}$ & $161,1 \pm 22,8$ & $157,8 \pm 22,3$ & 0,772 \\
\hline QRS, ms & $89,6 \pm 13,8$ & $82,6 \pm 13,6$ & 0,001 \\
\hline QTc, ms & $412,9 \pm 48,8$ & $496,4 \pm 45,5$ & 0,001 \\
\hline LVEF, $\%$ & $62,8 \pm 8,1$ & $56,8 \pm 8,2$ & 0,0001 \\
\hline LA diameter, $\mathrm{cm}$ & $4,3 \pm 0,7$ & $4,2 \pm 0,6$ & 0,988 \\
\hline RA diameter, $\mathrm{cm}$ & $4,1 \pm 0,5$ & $3,9 \pm 0,6$ & 0,140 \\
\hline
\end{tabular}

There was no differences between groups in age $(59,4 \pm 9,1$ in the ablation group and $56,4 \pm 8,9$ in the control group, $\mathrm{p}=0,068$ ) and gender $(46,3 \%$ were male in the ablation group and $46,6 \%$ in the control group, $\mathrm{p}=0,988$ ).

The AF duration was equal in the both groups $(53,2 \pm 45,8$ months vs. $51,4 \pm 46,6$; $\mathrm{p}=0,364)$.

In RFCA group prevailed paroxysmal and persistent form of AF (42,6\% vs. $25,9 \%$ and $52,2 \%$ vs. $27,5 \% ; p=0,001)$, meanwhile long standing persistent form of $\mathrm{AF}$ were more common for PRCT group (1,5\% vs. 46,6\%; $\mathrm{p}=0,001)$.

Patients on PRCT were significantly more symptomatic for HF in comparison to RFCA patients (the average value of NYHA class HF $2,2 \pm 07$ vs. $1,8 \pm 0,6 ; p=0,019$ ) (Figure 1), but AF for itself were more symptomatic in RFCA group (the average value of EHRA 3,1 $\pm 0,5$ vs. $2,9 \pm 0,6 ; \mathrm{p}=0,001)$ (Figure 2). 


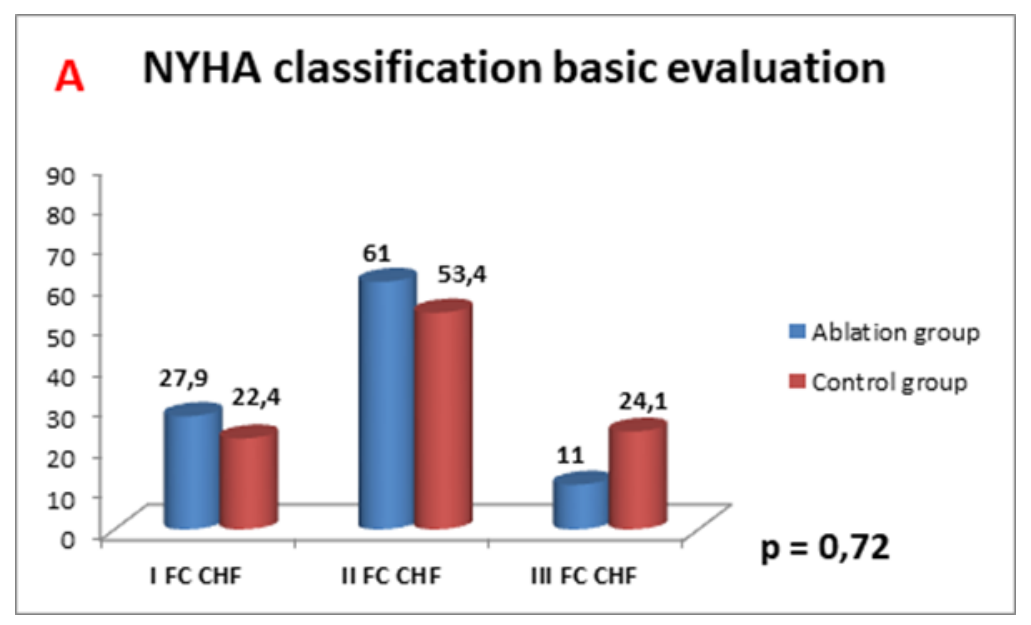

Fig. 1. NYHA score in groups at the basic patient's evaluation

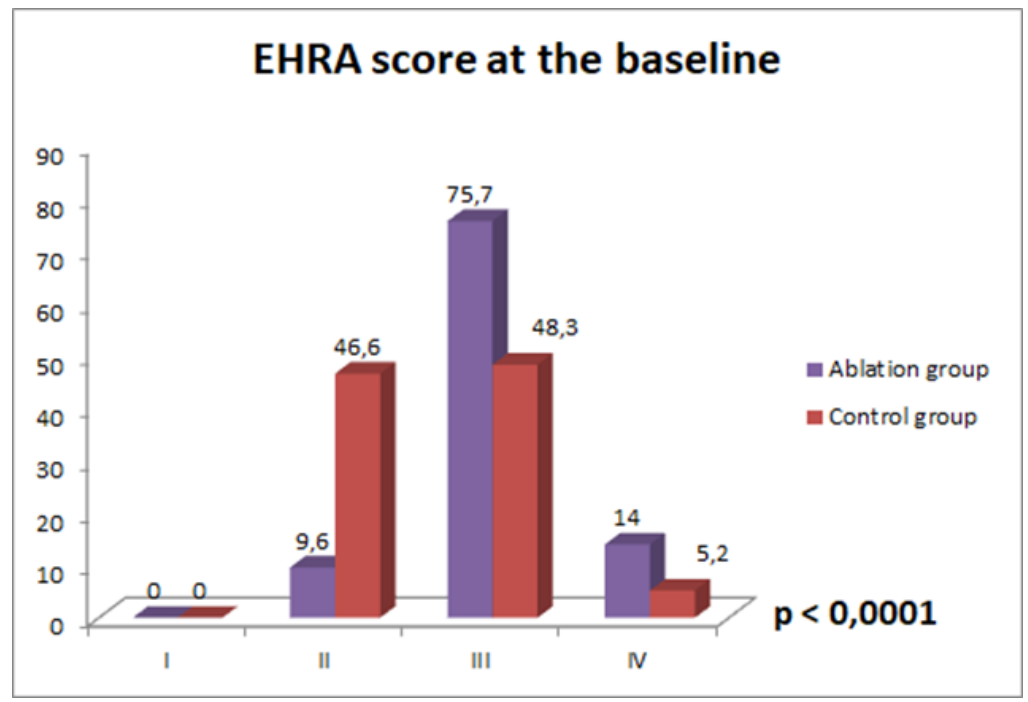

Fig. 2. EHRA class at the baseline

The vast majority of patients in both groups had a history of hypertension $(72,1 \%$ in the ablation group and $74,1 \%$ in MT group; $p=0,825)$. The history of coronary artery disease were more frequent in the RFCA group $(35,2 \%$ vs. $17,2 \% ; \mathrm{p}=0,016)$. ECG data showed significantly longer QTc interval in the control group $(496,4 \pm 45,5 \mathrm{~ms}$ vs. $412,9 \pm 48,8$; $\mathrm{p}=0,001)$ and shorter QRS complex duration $(82,6 \pm 13,6$ ms $\quad$ vs. $89,6 \pm 13,8 ; \mathrm{p}=0,001)$. ECHO parameters were comparable between the two groups, except for the LVEF - it was significantly higher in the RFCA group $(62,8 \pm 8,1 \%$ vs. $56,8 \pm 8,2 \%, p=0,001)$.
As data showed, BMI, mean CHA2DS2VASc, HAS-BLED scores, SBP, DBP, HR, the percentages of diabetes, stroke/TIA were comparable between the two groups.

Among patients with CHF with pLVEF who underwent RFCA and were followed-up 24 months $52,9 \%$ of patients remained free of $\mathrm{AF}$ recurrence; while in the control group the AFrecurrence number had reached $93 \%$ (table 2); the time of $\mathrm{AF}$ recurrence were earlier in the control group $(5,5 \pm 4,3$ months versus (vs.) $10,6 \pm 6,2$ months; 0,001) (table 2).

Table 2

The rate of $\mathrm{AF}$ recurrence in groups at 24-months follow-up

\begin{tabular}{|l|c|c|c|}
\hline \multicolumn{1}{|c|}{ Parameters } & $\begin{array}{c}\text { Ablation group } \\
\text { Total, } \mathbf{n = ~ 1 3 6}\end{array}$ & $\begin{array}{c}\text { Control group } \\
\text { Total, } \mathbf{n = 5 8}\end{array}$ & P value \\
\hline AF recurrence & $64(47,1)$ & $54(93)$ & 0,001 \\
\hline Time of AF recurrence & $10,6 \pm 6,2$ & $5,5 \pm 4,3$ & 0,001 \\
\hline
\end{tabular}


At the 24 months follow-up NYHA class significantly improved in ablation group
(Figure 3), as well as EHRA score (Figure 4).

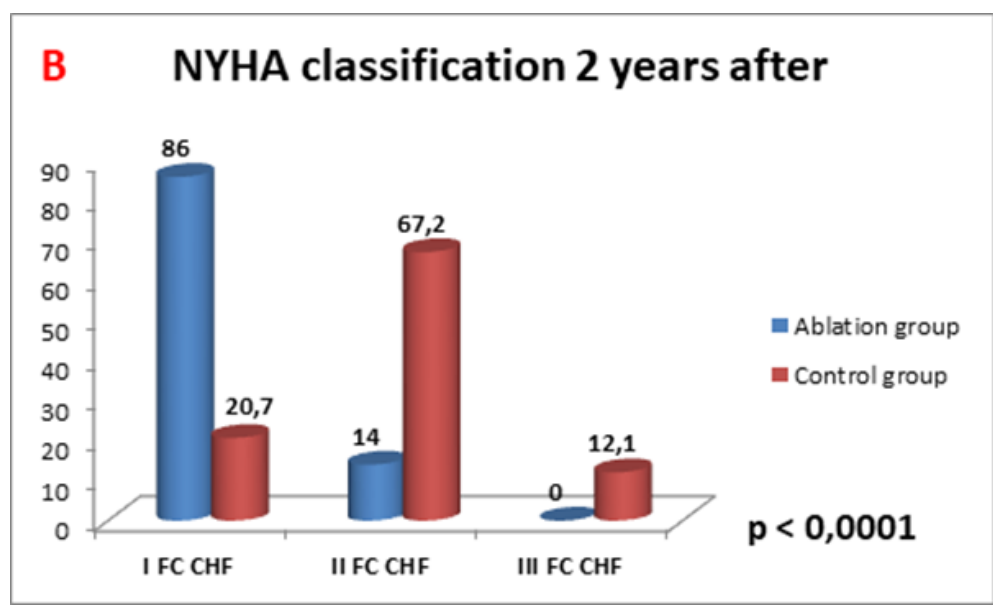

Fig. 3. NYHA score in groups 2 years after ablation

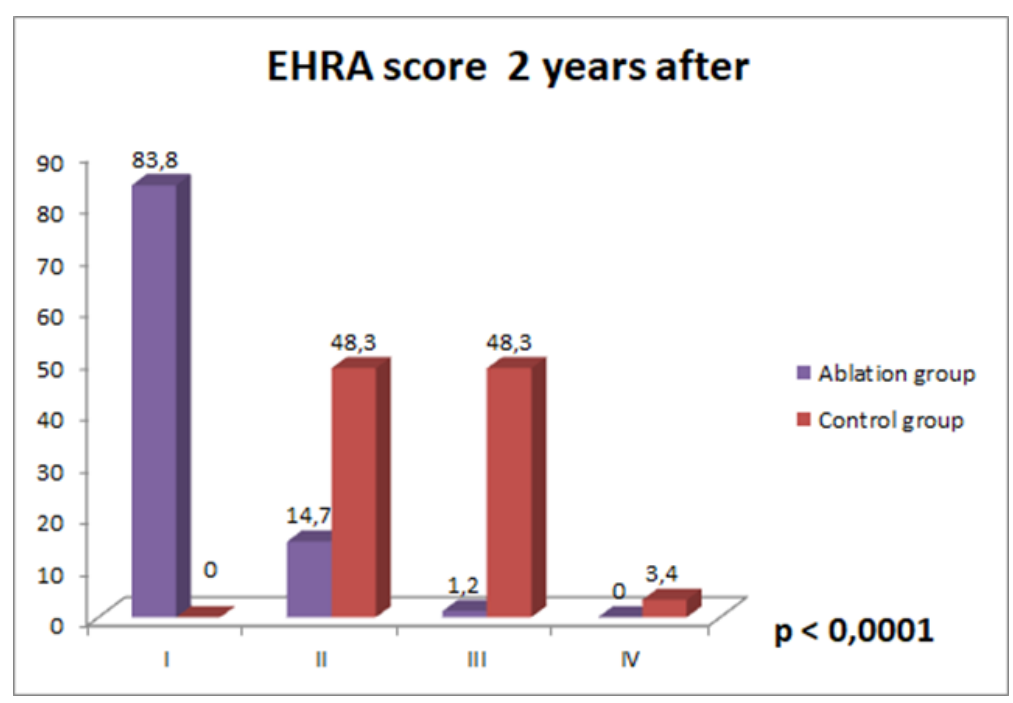

Fig. 2. EHRA class 2 years after

Follow-up echocardiography was performed at 24 months after the initial procedure/evaluation and was revealed that median absolute increase of LVEF from baseline in the RFCA group was
$1,42 \%$, while in the control group - median absolute decrease $-1,6 \%$, but this results were not statistically significant $(\mathrm{p}=0,324)$ (Figure 5).

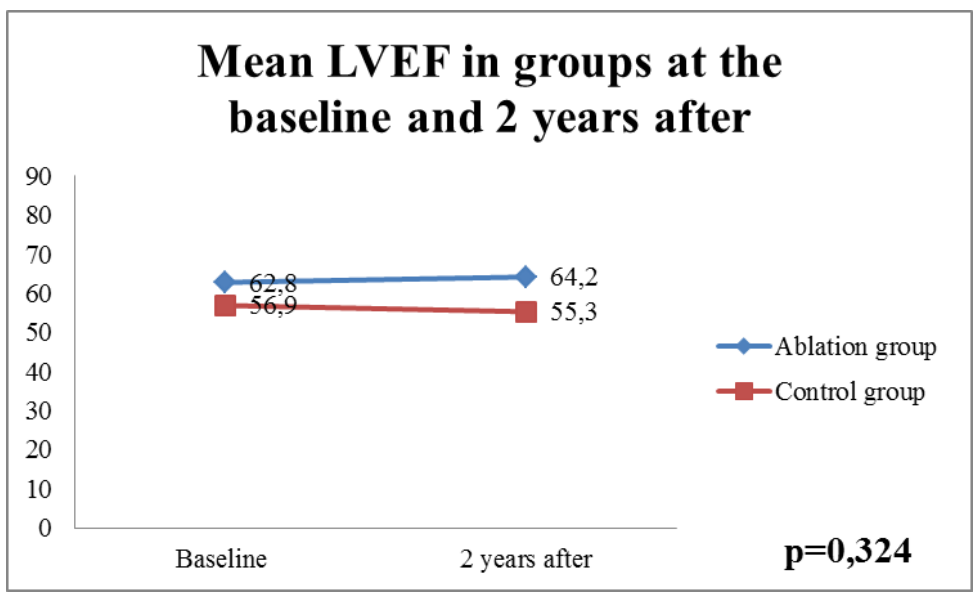

Fig. 5. The dynamics of mean LVEF in groups at the baseline and 2 years after 
Our study showed that radiofrequency catheter ablation for $\mathrm{AF}$ in patients with $\mathrm{CHF}$ with pLVEF associated with the long-term freedom from AF-recurrences, improved the clinical course of HF according NYHA class, the AF-related symptoms itself according EHRA score.

Several trials have reported improvements in clinical course with catheter ablation. In the CASTLE-AF trial (Catheter Ablation versus Standard Conventional Therapy in Patients with Left Ventricular Dysfunction and Atrial Fibrillation) was found catheter ablation for atrial fibrillation in patients with heart failure was associated with reduced the burden of atrial fibrillation, increased the distance walked in 6 minutes, and improved the LVEF. But this trial focused on the patients with HF with reduced LVEF at the baseline [7].

SARA study showed catheter ablation was superior to medical therapy as a strategy for maintenance of sinus rhythm in patients with persistent $\mathrm{AF}$ at 12-month follow-up and improved symptoms and quality of life in patients with symptomatic AF and reduces arrhythmia recurrence. Furthermore, CA had an acceptable safety profile according to the latest international registries [8].

Tachycardia affects the diastolic function by causing incomplete relaxation whereby the myocardium remains in a constant activated state that can be described as a partial or diastolic contracture. Lack of an atrial contribution to the ventricular filling can further worsen the diastolic function. Therefore, theoretically, HFpEF patients may obtain a greater benefit from rhythm control. However, there is a paucity of data available regarding the impact of catheter ablation on HFpEF [9].

In the study [10] the single procedure AF ablation and post-ablation AF freedom was the sole predictor of LV reverse remodeling after the procedure, which highlighted the importance of rhythm control on LV reverse remodeling.

\section{CONCLUSIONS}

1. Radiofrequency catheter ablation for rhythm control strategy in patients with heart failure with preserved left ventricle ejection fraction and atrial fibrillation associated with improvement the clinical course according NYHA class of heart failure comparing with pharmacological therapy, while improvement of left ventricle function is not statistically significant in this case.

2. Radiofrequency catheter ablation as a rhythm control strategy is more effective for prevention atrial fibrillation recurrences and atrial fibrillation-related symptoms itself.

\section{REFERENCES}

1. Batul S, Gopinathannair R. Atrial Fibrillation in Heart Failure: a Therapeutic Challenge of Our Times. Korean Circulation Journal. 2017; 47 (5): 644-662. DOI: 10.4070/kcj.2017.0040

2. Park J, Lee J, Yang P, Kim T, Shin E, Park J, Uhm J, Joung B, Lee M and Pak H (2017). Good responders to catheter ablation for long-standing persistent atrial fibrillation: Clinical and genetic characteristics. Journal of Cardiology, 69 (3), pp. 584-590. DOI: 10.1016/j.jjcc.2016.04.017

3. Shah S, Moosa P, Fatima M, Ochani R, Shahnawaz W, Jangda M et al. Atrial fibrillation and heart failureresults of the CASTLE-AF trial. Journal of Community Hospital Internal Medicine Perspectives. 2018; 8 (4): 208-210. DOI:10.1080/20009666.2018.1495979

4. Ponikowski P, Voors A, Anker S, Bueno H, Cleland J, Coats A et al. 2016 ESC Guidelines for the diagnosis and treatment of acute and chronic heart failure. European Heart Journal. 2016; 37 (27): 2129 2200. DOI:10.1093/eurheartj/ehw128

5. Hindricks G, Potpara T, Dagres N, Arbelo E, Bax J, Blomström-Lundqvist C et al. 2020 ESC Guidelines for the diagnosis and management of atrial fibrillation developed in collaboration with the European Association of Cardio-Thoracic Surgery (EACTS). European Heart Journal. 2020. DOI:10.1093/eurheartj/ehaa612

6. Lang R, Badano L, Mor-Avi V, Afilalo J, Armstrong A, Ernande L et al. Recommendations for Cardiac Chamber Quantification by Echocardiography in Adults: An Update from the American Society of Echocardiography and the European Association of Cardiovascular Imaging. Journal of the American Society of Echocardiography. 2015; 28 (1): 1-39.e14. DOI: 10.1016/j.echo.2014.10.003

7. Marrouche N, Brachmann J, Andresen D, Siebels J, Boersma L, Jordaens L et al. Catheter Ablation for Atrial Fibrillation with Heart Failure. New England Journal of Medicine. 2018; 378 (5): 417-427. DOI:10.1056/nejmoa1707855 
8. Mont L, Bisbal F, Hernández-Madrid A, Pérez-Castellano N, Viñolas X, Arenal A et al. Catheter ablation vs. antiarrhythmic drug treatment of persistent atrial fibrillation: a multicentre, randomized, controlled trial (SARA study). European Heart Journal. 2013; 35 (8): 501-507. DOI:10.1093/eurheartj/eht457

9. Cha Y, Wokhlu A, Asirvatham S, Shen W, Friedman P, Munger T et al. Success of Ablation for Atrial Fibrillation in Isolated Left Ventricular Diastolic Dysfunction. Circulation: Arrhythmia and Electrophysiology. 2011; 4 (5): 724-732. DOI: 10.1161/circep.110.960690

10. Ichijo S, Miyazaki S, Kusa S, Nakamura H, Hachiya H, Kajiyama T et al. Impact of catheter ablation of atrial fibrillation on long-term clinical outcomes in patients with heart failure. Journal of Cardiology. 2018; 72 (3): 240-246. DOI: 10.1016/j.jjcc.2018.02.012

\section{КЛІНІЧНИЙ ПЕРЕБІГ ХРОНІЧНОЇ СЕРЦЕВОЇ НЕДОСТАТНОСТІ ЗІ ЗБЕРЕЖЕНОЮ ФРАКЦІЕЮ ВИКИДУ ПІСЛЯ РАДІОЧАСТОТНОЇ КАТЕТЕРНОЇ АБЛЯЦІЇ ФІБРИЛЯЦІЇ ПЕРЕДСЕРДЬ}

Золотарьова Т. В., Бринза М. С.

Вступ. Нещодавні рандомізовані контрольовані дослідження дозволяють припустити, що катетерна абляція фібриляції передсердь (ФП) у пацієнтів із серцевою недостатністю (СН) призводить до поліпшення функції лівого шлуночка, фізичного навантаження та якості життя, але вони були зосереджені на СН із зниженою фракцією викиду лівого шлуночка (ФВЛШ).

Мета. Вивчити клінічний перебіг хронічної серцевої недостатності зі збереженою фракцією викиду після радіочастотної катетерної абляції при фібриляції передсердь.

Матеріали та методи. У дослідження було включено 194 пацієнта із ФП та хронічною СН зі збереженою фракцією викиду: 136 пацієнтів - пройшли катетерну абляцію (КА) з приводу ФП; 58 контрольна група, яка продовжувала фармакологічну терапію (ФТ) для стратегії контролю ритму. Усі пацієнти мали NYHA клас CH I, II або III, ФВЛШ >40\%. Базові характеристики включали демографічні та клінічні дані, результати ехокардіографії та електрокардіографії.

Результати. Пацієнти з ФТ мали значно більшу симптоматику щодо СН у порівнянні $з$ пацієнтами iз KA (середнє значення CH за класом NYHA 2,2 407 проти (пр.) 1,8 $\pm 0,6 ;$ p =0,019), але перебіг ФП був більш симптоматичним у групі КА (середнє значення EHRA $3,1 \pm 0,5$ пр. 2,9 $\pm 0,6$; p = 0,001). На 24-місячному етапі спостереження в групі КА 52,9\% пацієнтів не мали рецидивів ФП, тоді як в контрольній групі лише $7 \%$. Через 24 місяці подальшого спостереження клас NYHA значно покращився в групі абляції, а також клінічний перебіг аритмії за класом ЕНRА. Висновки. Радіочастотна катетерна абляція покращує клінічний перебіг хронічної серцевої недостатності зі збереженою фракцією викиду лівого шлуночка та зменшує інтенсивність симптомів, пов'язаних 3 фібриляцією передсердь.

КЛЮЧОВІ СЛОВА: серцева недостатність, катетерна абляція, фібриляція передсердь, клінічний перебіг

\section{ІНФОРМАЦІЯ ПРО АВТОРІВ}

Золотарьова Тетяна Володимирівна, асистент кафедри пропедевтики внутрішньої медицини i фізичної реабілітації Харківського національного університету імені В. Н. Каразіна, просп. Ак. Курчатова, 29, к. 1, пов. 3, кімн. 1, Харків, Україна, 61108. e-mail: tatiana.zolotarova@karazin.ua,_ORCID ID: https://orcid.org/0000-0001-62266769

Бринза Марія Сергіївна, кандидат медичних наук, завідувач кафедри пропедевтики внутрішньої медицини i фізичної реабілітації Харківського національного університету імені В. Н. Каразіна, просп. Ак. Курчатова, 29, к. 1, пов. 3, кімн. 1, Харків, Україна, 61108. e-mail: m.brynza@karazin.ua, ORCID ID: https://orcid.org/0000-0002$8260-3600$

\section{КЛИНИЧЕСКОЕ ТЕЧЕНИЕ ХРОНИЧЕСКОЙ СЕРДЕЧНОЙ НЕДОСТАТОЧНОСТИ С СОХРАНЕННОЙ ФРАКЦИЕЙ ВЫБРОСА ПОСЛЕ РАДИОЧАСТОТНОЙ КАТЕТЕРНОЙ АБЛЯЦИИ ФИБРИЛЛЯЦИИ ПРЕДСЕРДИЙ}

Золотарева Т. В., Брынза М. С.

Введение. Последние рандомизированные контролируемые исследования позволяют предположить, что катетерная абляция фибрилляции предсердий (ФП) у пациентов с сердечной недостаточностью $(\mathrm{CH})$ приводит к улучшению функции левого желудочка, физической нагрузки и 
качества жизни, но они были сосредоточены на $\mathrm{CH}$ со сниженной фракцией выброса левого желудочка (ФВЛЖ).

Цель. Изучить клиническое течение хронической сердечной недостаточности с сохраненной фракцией выброса после радиочастотной катетерной абляции при фибрилляции предсердий.

Материалы и методы. В исследование было включено 194 пациента с ФП и хронической СН с сохраненной ФВ: 136 пациентов - прошли катетерную абляцию (КА) по поводу ФП; 58 - контрольная группа, которая продолжала фармакологическую терапию (ФТ) для стратегии контроля ритма. Все пациенты имели NYHA класс CH I, II или III, ФВЛЖ > 40 \%. Базовые характеристики включали демографические и клинические данные, результаты эхокардиографии и электрокардиографии.

Результаты. Пациенты с ФТ имели значительно большую симптоматику по СН по сравнению с пациентами с КА (среднее значение СН по классу NYHA 2,2 \pm 0,7 против (пр.) 1,8 \pm 0,6; p = 0,019), но течение ФП было более симптоматичным в группе КА (среднее значение EHRA 3,1 \pm 0,5 пр. 2,9 \pm 0,6; $\mathrm{p}=0,001)$. На 24-месячном этапе наблюдения в группе КА 52,9 \% пациентов не имели рецидивов ФП, тогда как в контрольной группе только 7 \%. Через 24 месяца последующего наблюдения класс NYHA значительно улучшился в группе абляции, а также клиническое течение аритмии по данным класса EHRA.

Выводы. Радиочастотная катетерная абляция улучшает клиническое течение хронической сердечной недостаточности с сохраненной фракцией выброса левого желудочка и уменьшает интенсивность симптомов, связанных с фибрилляцией предсердий.

КЛЮЧЕВЫЕ СЛОВА: сердечная недостаточность, катетерная абляция, фибрилляция предсердий, клиническое течение

\section{ИНФОРМАЦИЯ ОБ АВТОРАХ}

Золотарёва Татьяна Владимировна, ассистент кафедры пропедевтики внутренней медицины и физической реабилитации Харьковского национального университета имени В. Н. Каразина, просп. Ак. Курчатова, 29, к. 1, эт. 3, комн. 1, Харков, Украина, 61108. e-mail: tatiana.zolotarova@karazin.ua,_ORCID ID: https://orcid.org/0000-00016226-6769

Брынза Мария Сергеевна, кандидат медицинских наук, заведующая кафедрой пропедевтики внутренней медицины и физической реабилитации Харьковского национального университета имени В. Н. Каразина, просп. Ак. Курчатова, 29, к. 1, эт. 3, комн. 1, Харьков, Украина, 61108. e-mail: m.brynza@karazin.ua, ORCID ID: https://orcid.org/0000-0002-8260-3600 